\title{
The relations between Poland and North Korea in 1948-1961
}

\author{
Sylwia Szyc | Wydział Humanistyczny, Uniwersytet Marii Curie-Skłodowskiej \\ w Lublinie, Biuro Badań Historycznych Instytutu Pamięci Narodowej
}

Słowa kluczowe: polityka zagraniczna PRL, Koreańska Republika Ludowo-Demokratyczna, stosunki

międzynarodowe, relacje polsko-północnokoreańskie, dyplomacja, wojna koreańska

Keywords: foreign relations of the People's Republic of Poland (PRL), the Democratic People's Republic of Korea, international relations, diplomacy, the Korean War

\section{Stosunki polsko-północnokoreańskie w latach 1948-1961}

\section{Streszczenie}

Pomimo przynależności do tego samego bloku ideologiczno-politycznego relacje polsko-północnokoreańskie ulegały licznym przeobrażeniom w latach 1948-1989. Niewątpliwie najintensywniejszym okresem współpracy obydwu państw była dekada lat pięćdziesiątych, na co wpłynęło między innymi zaangażowanie władz polskich w program odbudowy Koreańskiej Republiki Ludowo-Demokratycznej ze zniszczeń spowodowanych wojną koreańską, udział polskiej misji w pracach Komisji Nadzorczej Państw Neutralnych czy Komisji Repatriacyjnej Państw Neutralnych, a także przyjazd do Polski ponad tysiącosobowej grupy dzieci oraz studentów z Korei Północnej. Celem tego artykułu jest ukazanie wielowymiarowej płaszczyzny stosunków polsko-północnokoreańskich we wspomnianej dekadzie na polu współpracy politycznej, gospodarczej oraz kulturalnej, a także wpływu, jaki na ich kształt wywarły wydarzenia roku 1956, zmiany na podłożu ideologicznym, do jakich w tamtym czasie doszło w całym Bloku Wschodnim, oraz narastający konflikt pomiędzy Związkiem Sowieckim oraz Chińską Republiką Ludową.

\section{Abstract}

Even though Poland and North Korea both belonged to the Communist bloc, their relations were changing during the years 1948-1989. Undoubtedly, the increasing cooperation between these two countries might be observed in 1950s, when Polish authorities decided to help in the post-war reconstruction of the Democratic People's Republic of Korea. Poland contributed to the Neutral Nations Supervisory Commission and the Neutral Nations Repatriation Commission in Korea, and accepted a group of more than one thousand children and teenagers from North Korea. The aim of this article is to show the multidimensional character of the Polish-North Korean relations in the above-mentioned decade, including political, economic and cultural cooperation between these two countries. What is more, the article explains how some events, e.g. the 1956 events, the ideological changes introduced in the entire Eastern Bloc, or the growing conflict between the Soviet Union and the People's Republic of China, influenced the relations between Poland and North Korea. 


\section{Introduction}

The history of Polish-North Korean diplomatic relations can be traced back to 1948, when two not recognizing each other newly established post-war countries appeared - the Republic of Korea (South Korea) proclaimed in August and governed by the president Syngman Rhee, and the Democratic People's Republic of Korea (North Korea, the DPRK) proclaimed a month later and ruled, with the support of Joseph Stalin, by Kim II Sung.' According to the arrangements that had been made three years later, the border divining these two countries along the $38^{\text {th }}$ parallel was supposed to be temporary, ${ }^{2}$ however, it eventually became the meaningful symbol of the permanent division of Korea. On October 16, 1948, Poland, as one of the first countries officially recognized North Korea in the international arena (Labuda, Miechowicz 2002: 561), not accepting the government in Seoul at the same time. ${ }^{3}$

North Korea was a classic example of a satellite state dependent on the Soviet Union. Kim II Sung himself owed his political strength in the North Korean apparatus of government to Moscow patrons - they were the creators of his partisan legend (see Dziak 2000: 60-68). Establishing diplomatic relations between Poland and North Korea in October 1948 must be considered in the context of their affiliation to the Communist Bloc and can be related to Poland's recognition of Kim II Sung's legality of governance, which was an indication of Poland's support for the idea of unifying the Korean Peninsula under the communist government. As a response, North Korea approved the Oder-Neisse border between Germany and Poland and considered it as definite and inviolable (Tebinka 2010: 224). The part that DPRK played in the foreign policy of Poland in the discussed decade was mainly connected with the Korean War, which broke out on June 25, 1950 and which was the first major armed conflict during the Cold War. The events on the Korean Peninsula were also used for propaganda purposes, while help given to the authorities in Pyongyang, both in warfare and

\footnotetext{
${ }^{1}$ There are many incorrect forms of North Korean words in Polish, e.g. the name of the first North Korean leader, Kim II Sung, is generally known in Poland as Kim Ir Sen, and the capital city of this country is sometimes called Phenian, not Pyongyang as it should be called. In this article, the author uses McCune-Reischauer Romanization - a Korean language romanization system that is used in Poland. The exception are proper nouns that can be found in Polish source texts, as their transcription is incorrect.

${ }^{2}$ In the years of 1910-1945, the Korean Peninsula was occupied by Japan. The situation changed when, at the beginning of August 1945, Soviet and American forces entered Korea. Due to ongoing military operations and the provisions adopted during the Cairo, Potsdam, and Yalta Conferences, the Soviets and the Americans decided to divide the Korean Peninsula into two temporary occupation zones. Soviet and American forces were supposed to stay on the peninsula until the decision about Korea would be made. The division of these two countries along the $38^{\text {th }}$ parallel was the idea of Dean Rusk and Charles H. Bonestell. It wasn't motivated by any geographical, historical or economic reasons. The main argument supporting this separation was the fact that a line of demarcation divided Korea into two almost equal parts. The United States was administering the agricultural South, while the Soviet Union was taking over the industrial North (Lowe 1995: 22-23; Burdelski 2004: 33; Hastings 2010: 26-27; Strand 2014: 38-39).

${ }^{3}$ Due to the transformation of political system in Poland in 1989, on November 1, 1989, Poland established diplomatic contacts with the Republic of Korea. As a consequence, the relations between Warsaw and Pyongyang became cool, yet not suspended.
} 
a couple of years after by the rest of satellite states, was supposed to consolidate the picture of the strong and supportive Eastern Bloc.

The aim of this article is to show the diversity of Polish-North Korean relations on the political, economic and cultural front in the 1950s, as well as how the events from 1956 influenced these relations. Considering the multifaceted nature of this issue, this article will discuss the years of 1948-1961, starting with the establishment of diplomatic relations up till the post-war restoration of the Democratic People's Republic of Korea, final dealing with Stalinism in 1961, as well as the aggravation of Russia-North Korea relations a year later (which can be perceived as a symbolic end of increased cooperation between Poland and North Korea). ${ }^{4}$

Polish-North Korean cooperation in the discussed period can be divided and analyzed according to three main stages. The first stage was the Korean War (1950-1953) - Poland actively supported the regime in Pyongyang, especially its propaganda. In this period, the diplomatic outpost of both countries were opened. The next stage (1953-1956) was connected with Poland's involvement in the international plan of reconstructing North Korea after the war ${ }^{5}$ as well as Poland's contribution to the Neutral Nations Supervisory Commission and the Neutral Nations Repatriation Commission in Korea. The last stage refers to the years of 1955/1956-1961 when the Eastern Bloc significantly changed its ideological position and when the North Korean authorities supported Beijing in the conflict with Kremlin.

\section{Poland's involvement in the Korean War (1950-1953)}

The opening of Polish diplomatic outpost in the DPRK ran parallel to the war on the Korean Peninsula. On June 7, 1950, only a few days before the war broke out, Poland and North Korea signed the agreement on exchanging diplomatic representatives in the position of ambassadors. The first Polish charge d'affaires in North Korea was Stanisław Dodin (appointed a month later) and the first ambassador ${ }^{6}$ was Juliusz Burgin (appointed in September, he was also the ambassador in the People's Republic of China since February 1950) (Szyc 2015a: 226-229). It is worth noting that in the discussed period the Polish Embassy was one of the four accredited missions in North

\footnotetext{
${ }^{4}$ The issue was broadly discussed in the article "An overview of the relations between Poland and North Korea" written by Nicolas Levi and Anna Naumczyk. The article discussed the years of 1948-1980. See Levi, Naumczyk 2012: 68-93.

${ }^{5}$ The three-year plan of reconstructing the North Korean economy was implemented in the years of 19541956. Poland, as well as other countries of "people's democracy", got also materially and financially involved into the five-year plan of reconstructing of the DPRK, however, comparing with earlier years, their help was limited. The exception was the aid offered by the USSR and the PRC - it was the result of the Sino-Soviet conflict. The countries were competing on political power in North Korea.

${ }^{6}$ During the discussed period, the following politicians served the office of Polish ambassadors in North Korea: Juliusz Burgin (1950-1951), Stanisław Kiryluk (1952-1954), Jerzy Siedlecki (1954-1959), Józef Dryglas (19591963). See Szyc 2015a: 224-238.
} 
Korea. ${ }^{7}$ The first months of its existence were marked by dynamic warfare. While corresponding with the Ministry of Foreign Affairs in Poland, Burgin wrote how difficult was their work in the embassy - at that time it was located in a mountain village called Manpo, which was on Chinese-Korean border. Due to its strategic location and proximity to the battlefront, from January 1951, this area was frequently bombarded (Juliusz Burgin's report...: 3-4). The North Korean Embassy in Warsaw was opened in the middle of 1951. The first head of the North Korean diplomatic mission, ${ }^{8} \mathrm{Choi} \mathrm{Ir}$, was closely connected with Kim II Sung and his people, as their relations dated back to the anti-Japanese guerilla. Just before Choi Ir arrived to Poland, he had served as the first counselor in the North Korean Embassy in China (Biography of Cze-Ir: 1).

Poland, as well as other countries of "people's democracy" (apart from the PRC), didn't take a direct part in the Korean conflict. However, the affiliation to the Eastern Bloc obliged Poland to help its Asian ally. Because of recovery and reconstruction in the aftermath of World War II, Poland's support had mainly propagandist dimension.

During the first weeks of the armed conflict, the international protest campaign called "Ręce precz od Korei" ("Hands Off Korea") was started. The aim of this campaign was to criticize the authorities in Seoul as well as the UN army that supported Seoul they were blamed for the outbreak of the war that at any time could have changed into a global nuclear conflict (Neścioruk 2014: 126-132). The campaign was associated with many other events which had a nationwide and local rage. On 10-17 July, as part of "the global week of active solidarity with Korea", numerous demonstration were organized throughout Poland. The largest demonstration was held on Mariensztat in Warsaw - the official statistics say that there were more than one hundred thousand of participants (Leszczyński 1995: 56-57). The Polish Committee for the Defense of Peace (PCDP) with the help of the Union of Polish Youth, the Society of Fighters for Freedom and Democracy, the League of Women, the Children Friend's Association, or the Polish Teachers' Union held the collection of money, clothes, medicine and food which were then given to people in the DPRK (Kim 2014: 164). The first big delivery to Asia was sent in March 1951 (Letter to Minister Naszkowski: 8). Between 1950 and 1951, they even organized the collection of gifts for Korean children (Kim 2014: 163). In terms of organization and mass agitation, the abovementioned events were based on one of the biggest propaganda campaigns at that time - collecting signatures by the PCDP to support the Stockholm Appeal ${ }^{9}$ that had been approved at the end of March 1950. The propagandist vision of war in Korea authenticated the Soviet Union as the leader of "the global movement for the defense of peace" which, along with

\footnotetext{
${ }^{7}$ Other countries that had their representatives in North Korea in the rank of ambassadors were the Soviet Union, China and Mongolia. When it comes to Hungary, Czechoslovakia and Bulgaria, they were represented by diplomatic missions.

${ }^{8}$ During the discussed period, the following politicians served the office of North Korean ambassadors in Poland: Ho Gook Bon (1954-1958), Choe Bin (1958), Kim Haek In (1959-1962). See Szczepanik, Herman-Łukasik, Janicka 2010: 159.

${ }^{9}$ More about the Stockholm Appeal and the activity of the PCDP, see Łagojda 2017: 1034-1061.
} 
other countries of "people's democracy", was supposed to stop nuclear armaments and rescue the world from another major armed conflict.

The propaganda activities could be also observed in the press - it was full of statements of politically-conscious workers who agitated for increasing work efficiency, as it would be another way to fight with an "imperial enemy" (Leszczyński 1995: 58). Video footage of the events on the Korean Peninsula was often used by the Polish Film Chronicle (Matusik 2015: 564-569).

In April 1951, the delegation of the Polish Committee for the Defense of Peace and the chairman of the Central Council of Trade Unions, Marian Czerwiński, went to North Korea in order to give Koreans the medicine that had been collected by trade unions (Letter to Minister Naszkowski: 8). The Catholic Church joined the fundraiser, but, to the great dissatisfaction of the authorities, it didn't use "as strong political overtone as it was demanded" (Kim 2014: 167). The PCDP provided North Korea with help till the end of the Korean War in 1953.

The solidarity with North Korea could be also seen on the artistic field, as the war themes dominated the early stage of socialist realism (Czyżewski 2005: 157). Many journalists, writers and poets dedicated their works to North Korea, e.g. Jan Brzechwa or Wisława Szymborska (Brzechwa 1952: 74; Szymborska 1952: 24). The Korean War became also the theme of a few novels for children and teenagers. Marian Brandys in his books "Dom odzyskanego dzieciństwa" ("The House of Regained Childhood") and in the reissued version of this book, "Koreańczycy z Gołotczyzny" ("The Koreans in Gołotczyzna"), wrote about war orphans who stayed then in Poland (Brandys 1953; Brandys 1954). When it comes to painting, the most important representations of the Korean conflict and one of the best known examples of socialist realism is "Matka Koreanka" ("Korean Mother) painted by Wojciech Fangor. On the huge canvas we can see a dead body of a woman and a few years old child who wants to scramble on her. In the background there are burning houses. Everything is painted in monochromatic grey colors - the tone highlights how tragic the whole situation is. Art in the service of communist propaganda was supposed to authenticate the version of events on the Korean Peninsula presented in the Eastern Bloc. It was also making them more emotional. One of the popular methods used by the authorities was referring to the traumatic events from World War II and comparing the operations of the US army to those undertaken by Nazi Germany (see Broniarek 1952: 12; Korotyński 1952a: 22-23; Korotyński 1952b: 42; Pracki 1953: 152; Szymborska 1952: 24).

The purpose of this ideological war waged by the authorities was to convince the society that the government in Seoul was the one to be widely blamed for the Korean War. The society was supposed to be confirmed in the belief that the DPRK, along with their leader Kim II Sung, was the only legal representative of the Korean nation. What is more, the aim of the authorities was to make people suspicious about the West as well as to show the integrity of the Eastern Bloc which was actively involved 
in supporting the DPRK. In the official statements, the peaceful policy of North Korea and its allies was constantly being compared with the aggressive government in Seoul which was portrayed as a mere puppet of the US government. Contrary to official propaganda used by the authorities, the Polish society perceived the Korean War as the chance of overthrowing communism - people expected a quick victory of the UN army which could then move to Moscow (Jarosz 1997: 55).

North Korea wasn't only supported by official propaganda but also it was given some material aid. Despite many difficulties connected with rebuilding Poland after the damages of World War II, on $2^{\text {nd }}$ June 1952, both countries signed the agreement on supplying of goods on credit terms from Poland to North Korea for the years of 19511952 (Szczepanik, Herman-Łukasik, Janicka 2010: 166). Nevertheless, early in the following year, the National Council of the People's Republic of Poland relived North Korea of most of these obligations (Labuda, Miechowicz 2002: 602, Resolution no. 140/53 ...: 1). A nearly forgotten event in the history of Polish-North Korean relations during the war was the arrival of 1200 children and teenagers from the DPRK to Poland (they later became the main characters of Marian Brandys' novels mentioned earlier in the article) (see Sołtysik 2009: 195-210; Sołtysik 2010: 57-95; Szyc 2014a: 1045-1054; Szyc 2014b: 155-164). In spring 1951, the authorities of North Korea requested "fellow countries" to adopt and raise war orphans. Apart from Poland, Bulgaria, China, Czechoslovakia, Romania, the German Democratic Republic, the Soviet Union, and Hungary also decided to help North Korea in this matter.

In November 1951, 200 children at the age of 12 to 16 came to Poland (Written account of the conversation with the Second Secretary of the North Korean Embassy, Li Sen Yen: 4). First, they were put in an orphanage in Gołotczyzna, near Ciechanów, but then, in July 1953, they were moved to the State Childcare Centre in Świder, which was located near Otwock. The second and at the same time the largest (1000) group of children at the age of 5 to 15 came to Poland in July 1953 (Report on North Korean missions...: 3). The children were put in the former hospital buildings in Płakowice, near Lwówek Śląski in Lower Silesia (it was also the place where the Greek and Macedonian children stayed). The Korean children were accompanied by a group of educators who were supposed to give them the ideological upbringing and to teach them the Korean language and culture. Poland covered all the expenses connected with their arrival and stay. In accordance with the decision of the authorities in Pyongyang, the children came back to their motherland in 1959 (the first decisions had been made two years earlier). The official reasons given by the DPRK were that it had completed the 3-year plan of reconstruction (Written account of the conversation with Li Son-Lon...: 14) and that the economic conditions in the country had improved. However, it could have been the result of a critical attitude of the Worker's Party of Korea to the liberalization of Polish political system. After their return to North Korea, the children's contact with their former educators was gradually reduced. The reason was to make it possible for the children to assimilate again, as the living conditions 
in the "people's democracy" countries were more difficult than those in Europe (Case of the return of North Korean orphans...: 1-2). The abovementioned attitude of the DPRK to "Gomułka's thaw" definitely had an impact on this case - the authorities were afraid that Polish ideas would be brought to North Korea. Polish teachers were receiving emotional letters for a few years after the children had left Poland, but then, at the beginning of the 1960s, their contact was completely lost.

What is more, at that time, a group of Korean students from the vocational and technical school was educated in Poland. Also some Korean students in the academic year of 1952-1953 started their education at Polish universities. It is worth mentioning that in the 1950s the students form the DPRK accounted for the largest part of the population of foreign students in Poland (Table presenting the number of foreign students...: 286). This tendency changed in the 1960 s when Korean students had to leave Poland as well.

\section{"Fraternal help" in the post-war restoration of North Korea}

The 3-year Korean War brought a "bloody harvest". Waldemar Dziak called it a "weird war" which "started as a civil war and ended as an international war involving 20 countries" (transl. from Dziak 2000: 180). After a great deal of negotiation, on July 27, 1953, in the village Panmunjom which is on the border of both Koreas, the ceasefire was announced. One of the provisions of the agreement was maintaining the separation of these two countries along the $38^{\text {th }}$ parallel and creating a $4 \mathrm{~km}$-wide demilitarized zone. They also made the arrangements about war prisoners (Gaj, Zuziak 2011: 24). The Neutral Nations Supervisory Commission (NNSC) controlled the ceasefire not to be violated. Both Koreas proposed for the commission their representatives. North Korea chose Poland and Czechoslovakia, while South Korea Switzerland and Sweden (Resolution no. 686/53...: 24). Additionally, the Neutral Nations Repatriation Commission was appointed - it was composed of the representatives of the abovementioned countries and India ${ }^{10}$ (Resolution no. 685/53...: 10).

The main duties of NNSC ${ }^{11}$ (which, actually, exists to this very day) are to control the exchange of military staff, arms and equipment, as well as to react to any incident in the demilitarized zone. Polish representatives of the commission had been chosen by the Ministry of National Defense in consultation with the Ministry of Foreign Affairs and the Ministry of Public Security (Resolution no. 686/53...: 24). Due to difficult working conditions the representatives of NNSC were frequently replaced, so on $28^{\text {th }}$ November 1953 the National Council of the People's Republic of Poland created the special Military Unit No. 2000 which was to train future workers (Resolution

\footnotetext{
${ }^{10}$ According to the Resolution of the Presidium of the Government, the Commission consisted of 51 representative chosen by the Ministry of Foreign Affairs. See AAN, 159/80, Uchwała nr 685/53 Prezydium Rządu z dnia 12 września 1953 r. w sprawie utworzenia, wyposażenia i utrzymania przedstawicielstwa PRL w Komisji Repatriacyjnej Państw Neutralnych w Korei: 10.

${ }^{11}$ See Burdelski M., 2008: 310-313; Birchmeier, Burdelski, Jendraszczak, 2003.
} 
no. 910/53...: 6). The representatives of the Commission were the Polish Army soldiers, translators and staff of the Ministry of Foreign Affairs and the Ministry of Home Affairs (Levi 2009: 352), and the first head of Polish party (which numbered more than 330 people) was brig. gen. Mieczysław Węgrowski (Benken 2014: 440). ${ }^{12}$

The actions taken by NNSC in the 1950s generated great tensions between North and South Korea. The Republic of Korea and supporting it UNO believed that North Korea, contrary to the provisions of the agreement, was still militarizing. At the end of May 1956, the activities of the Polish and Czechoslovakian representatives in North Korea were suspended. It was perceived by Poland as a breach of the Panmunjom agreement (Tebinka 2010: 223-224). After this event, a group of Polish representatives was significantly reduced and in 1960 it had only 10 members (Birchmeier, Burdelski, Jendraszak 2003: 29).

During this period, the relations between Poland and North Korea were mainly determined by the help given to the DPRK by some of the satellite states for the post-war restoration. Both the DPRK and China have never published any official statement about the loss they suffered because of the war. It may be assumed that as a result of the Korean conflict, 6 million people were killed or injured and 1 million of them were from North Korea (Strand 2014: 180). War damages were visible on the whole northern part of the peninsula - almost every town and industrial area had been bombarded (Armstrong 2013: 48). Restitution was a big challenge for both Korean states, but thanks to a substantial help of the satellite states, during the first two decades after the war North Korea was able to develop more quickly than its southern neighbor.

At the end of July 1953, Kim II Sung asked a soviet ambassador in Pyongyang, Siergiej Suzdalew, if the USSR could help in the post-war reconstruction of North Korea (Armstrong 2005: 162-163). Following Kremlin, the economic and material support was provided by China, East Germany, Poland, Czechoslovakia, Romania, Hungary, Bulgaria, Albania, Mongolia, and North Vietnam. The participation of each satellite state in restitution in the DPRK was different and depended on their capabilities. According to Armstrong, "[t]he period of post-war reconstruction in North Korea was the first and only time the Soviet Union, China and the Soviet-aligned countries of Eastern Europe and Mongolia cooperated in a multilateral development project of such scale" (Armstrong 2005: 162).

In 1953 Stefan Pietrusiewicz was nominated as the Polish government plenipotentiary for Korea - at that time he held a position of the undersecretary of state in the Ministry of Industrial Construction. The initial form of help for North Korea was defined by the resolution of the National Council of the Polish People's Republic dated 24 September, 1953 (Resolution no. 732/53...: 11). It stated that Poland would be obliged to build a steam engine and carriage workshop in Pyongyang and a rolling-stock

12 The heads of Polish representatives in NNSC for the years of 1953-1961: 1953 - brig. gen. Mieczysław Wągrowski, 1954-1955 - brig. gen. Leszek Krzemień, 1958-1960 - brig. gen. Leo Sament, 1960-1961 - brig. gen. Tadeusz Kunicki. 
workshop in Wonsan as well as to implement the mechanization of three coal mines chosen by the Koreans. What is more, Polish urbanists developed the plan of a NorthKorean city and the plan of two housing projects in Wonsan and Pyongyang. At the same time, Poland joined the plan of reconstructing North-Korean infrastructure. In 1953 the construction of the Polish Red Cross Hospital in Hŭich'ŏn was started - it was completely equipped by Poland. Two years later it was handed over to the Koreans and several hundred health professionals were sent to North Korea..$^{13}$ On November 11, 1953 Poland and North Korea signed the agreement on the free supply of goods from Poland to North Korea and on the free supply of Polish armament and military equipment, both for the years of 1953-1954 (Szczepanik, Herman-Łukasik, Janicka 2010: 166-167).. The Polish support of the restitution in North Korea was broadened on $14^{\text {th }}$ January 1955 when both countries signed another agreement on free financial help that would be given to the DPRK in the years of 1954-1957, with a maximum amount of 364 million PLZ (Note on the economic relations...: 17).

\section{The way towards transformations}

Joseph Stalin's death in 1953, the ideological changes brought by Nikita Khrushchev's leadership, and growing conflict between the USSR and China - all of these had a considerable impact on the Polish-North Korean relations. Pyongyang and Warsaw had been engaged in a political dialogue until the orthodox communist regime existed in Poland. Even though both countries were more and more distant from each other, they both avoided public criticism of their actions. The ceasefire signed in July 1953 in Panmunjom and sticking to the prewar borders between two Koreas weren't satisfactory for Kim II Sung - he still hadn't abandoned the idea of extending his authority on the whole peninsula. It seemed that the military defeat in the Korean war would weaken his political position or even that his opponents would try to take over the control of the country. In truth, he had lost his major political supporter, Joseph Stalin, and had to face with the changes of Stalin's successor. However, Kim knew how to turn failure into success and his cult and position in the authority apparatus got even stronger (Dziak 2000: 189-191, 210-214; Szalontai: 37-43).

At the time of the conflict, a North-Korean leader was perceived by the world as a puppet of the Soviet Union because he obeyed any instructions given by Stalin (Dziak 2000: 191). The death of the soviet dictator and then the new leadership of Nikita Khrushchev made a dependence on Moscow less strong in all of the countries of the Eastern Bloc. Kim had successfully taken advantage of this situation.

As the influence of the Soviet Union in this region had been reduced, neighboring China was aspiring to gain the leadership in the Easter Bloc. It is worth noticing that at

${ }^{13}$ Due to the ceasefire signed at the end of July 1953, the field hospital of the Polish Res Cross was turned into the civilian hospital and divided into two parts. Apart from Hŭich'ŏn, the hospital was also organized in Hamhŭng, on the site of North Korean hospital which had been bombed. 
that time the relations between Beijing and Pyongyang weren't friendly. The reasons behind this situation were that, because of the series of military losses, Kim had been removed from making important strategic decisions in the Korean conflict and that in November 1950 the army of "Chinese volunteers" joined the war (Dziak 2009: 28; Bayer, Dziak 2006: 176). The neighbors became close again when in 1953 the North Korean delegation visited Beijing and negotiated substantial financial and material aid for the post-war restoration of their country. Apart from financial help, which was the second greatest source of help for North Korea from the Soviet States (Shen, Xia 2012: 6), the PRC strengthened its position in North Korea by sending there more than half a million workers who were the soldiers form the Chinese People's Liberation Army. They were stationed in North Korea until 1958 (Armstrong 2005: 164).

The early post-war years in North Korea were not only the time of restoration of the country, but also the years of political purge and repression which became an important part of Kim's dictatorial rule. Political repression involved the military command of the Korean People's Army, who were burdened a responsibility for defeat in the Korean War, and all of the political opponents in the Workers' Party of Korea (Dziak 2000: 184, 210-215).

The normalization of Soviet-Yugoslavian relations and the Belgrade Act signed in 1955 , both actually expressed the acceptance of two different ways of building socialism. Kim II Sung's willingness to new political ideas independent of Moscow and Beijing was expressed by the concept of Juche. The first documented reference to Juche as an ideology appeared on December 28, 1955, in a speech given by Kim entitled "On Eliminating Dogmatism and Formalism and Establishing Juche in Ideological Work". Juche was supposed to adjust communism to North Korea as well as it was one of the tools to fight with political fractions ${ }^{14}$ (Dziak 2000: 215-221; Myers 2015: 45-55; Armstrong 2013: 90). It was a "new approach" to the development of North Korea, different from the one used in the past, when North Korea was dependent on China, then on Japan (1910-1945), and on the USSR (from 1945) (Armstrong 2013: 53).

Nikita Khrushchev's "Secret Speech" given on the $20^{\text {th }}$ Congress of the Communist Party of the Soviet Union in February 1956 was a serious threat to the ideological foundations of the entire Eastern Bloc. For Kim II Sung it was not only a threat to the safety and integrity of the entire Easter Bloc, but, more importantly, he was afraid of losing his dominance in the North Korean political scene. Kim saw some discrepancies between his and Khrushchev's visions of communism. He didn't agree with the peaceful coexistence policy propagated by the Soviet leader (Kim wanted to spread a communist revolution under his leadership on the whole peninsula), the new economic policy of the USSR (it rejected the heavy industry as the main sector of North

\footnotetext{
${ }^{14}$ It is worth noting that the idea of Juche, till the middle of 1960s, was a mere symbol, and only during the $5^{\text {th }}$ Congress of the Central Committee of the Workers' Party of Korea in November 1970, it became the official ideology of the country.
} 
Korean economy), and most of all, he was dissatisfied with denouncing the personality cult ${ }^{15}$ and Stalinist way of maintaining power.

Nevertheless, the leader of the DPRK couldn't reject all the provisions of the $20^{\text {th }}$ Congress, mainly because of economic and military reasons. Due to a difficult political position of the country as well as to the fact that the implementation of a next economic plan was dependent on the support of the Soviet Union and China, Kim II Sung developed the policy that was neutral, skillfully maneuvering between two powerful neighbors (he followed this policy almost to the end of the Sino-Soviet conflict). Despite a serious tension in relations with Kremlin, North Korea didn't completely sever its diplomatic relations with other satellite states that supported Khrushchev's ideas. However, they were getting worse.

Despite many difficulties that occurred in the Eastern Bloc, in 1956 Poland and North Korea had many occasions to develop their relations. In January, the head of the Supreme People's Assembly of the DPRK, Kim Tu Bong, visited Warsaw (Szczepanik, Herman-Łukasik, Janicka 2010: 160), and on 11 $11^{\text {th }}$ May 1956 in Pyongyang, the Polish People's Republic and the DPRK signed the agreement on cultural cooperation (Political report of the Embassy of Polish People's Republic in the DPRK for the period from 15 April to 15 May 1956).

Just a few days before the visit of the North Korean delegation (led by Kim II Sung himself) that was planned on 2-6 July 1956 (see Szyc 2016: 280-289), workers organized massive protests in Poznań which were brutally suppressed by the government (see Machcewicz 1993; Makowski 2001; Codogni 2006). There were various reasons behind those demonstrations. One of them was the deterioration of the living standards of workers. Khrushchev's speech and its reception in Poland was also significant for this case. At the same time, the details of Khrushchev's speech had never seen the daylight in North Korea - according to Kim's decisions, only a small and trusted group of active members of the party was informed about the speech (Szalontai 2005: 8687). In North Korea a public discussion about the "mistakes and distortions" could not have started.

The first visit of Kim II Sung in Poland was a part of a 50-day journey to the countries of "people's democracy". The North Korean delegation visited (in a chronological order): the Soviet Union, the German Democratic Republic, Romania, Hungary, Czechoslovakia, Albania, Poland and Mongolia. Its main goal was to receive more "fraternal help" while introducing the next economic plan in the years of 1957-1961. Nevertheless, Kim II Sung wasn't satisfied with this visit, as Poland's support for North Korea remained at the same level (Note of the Deputy Director of Department $V$ of the Ministry of Foreign Affairs, Edward Słuczański...: 47).

${ }^{15}$ More about the personality cult in the DPRK after the $20^{\text {th }}$ Congress, see Dziak 2000: 230-234 ; Szalontai 2005: 87-90. 
Pyongyang was carefully monitoring the Poznan 1956 protests and Władysław Gomułka's rise to power in October 1956, however, this information didn't reach North Korean society (Szalontai 2005: 111). The information presented by the North Korean media was limited to reprints form a soviet newspaper "Pravda" ("Truth") and very often published with a few days delay and without any comment (Note on media reports...: 1). In this period, the popularization of foreign culture and art in North Korea was limited, especially when it comes to the Soviet Union (Dziak 2000: 240-241). In 1955 none of the plays form the countries of "people's democracy" were staged in North Korean theatres. Also the number of foreign books available on the market was reduced (Written account of the conversation between the First Secretary...: 13).

North Korea was cautious about the political changes that had been made in Poland. Kim II Sung perceived the Poznań protests as the result of too liberal Polish politics towards the intellectuals, which was, as he believed, faulty (Lankov 2007: 146). Romania and Albania and their style of rule were, on the contrary, good examples to follow - in both countries de-Stalinization wasn't introduced on a larger scale and, what is more, in the 1950s and the 1960s they tighten up their policy toward Moscow. The Minister of National Security, Choe Chang lk, was of the same opinion. According to Changik, in 1956 Polish politicians made three mistakes: they revealed too much information about the decisions made during the $20^{\text {th }}$ Congress, they lacked strong political leadership, and there was no effective control over social moods (Lankov 2007: 89).

In 1957, the Polish Embassy in North Korea reported to the government in Warsaw that the highest North Korean authorities were convinced that "the socialist policy and methods that had been used in North Korea were absolutely accurate", including the personality cult of Kim II Sung (Political report of the Embassy of Polish People's Republic in the DPRK for the period from 1 April to 3 July 1957: 3-5). Drawing on the recent experience of Poland and Hungary, the North Korean leader was aware of the possible dangers resulting from de-Stalinization, liberation of community life, social protests against lowering living conditions ${ }^{16}$ or their possible occurrence in North Korea (Scalapino, Lee, 1972a: 540; Armstrong 2013: 100).

All of these worries seemed to be confirmed by the fact that many North Korean citizens who were abroad didn't want to come back to their motherland. At the end of May 1957, the officers of the Ministry of Foreign Affairs caught two students of technical school in Szopienice in Lower Silesia who wanted to flee to the GDR and then further to the Western Europe (Written account of the conversation with the Charge d'Affaires...: 4). Less than a month later, the Embassy of the DPRK in Warsaw was informed about yet another run away attempt organized by North Korean students. This time the would-be fugitives tried to contact the American Embassy in Warsaw

\footnotetext{
${ }^{16}$ One of the decisions that had been made was a $35 \%$ raise for the budget sector workers, while the price of medicine, sugar and soft goods was lowered by $25 \%$. What is more, daily combat ratio of an average North Korean citizen was increased by $100 \mathrm{~g}$. Despite the measures that were taken, the living standards in North Korea didn't improve a lot. The political authorities wanted also to place a stronger emphasis on good communication with the society. See Dziak 2000: 245-246; Scalapino, Lee 1972b: 542.
} 
twice by mail - they asked for help in entering the US. As the letters were intercepted by the police and the U.S. Embassy didn't respond to the requests, next time the students sought help in the French Embassy. Three students were detained in this case (Written account of the conversation with the Ambassador of the DPRK in Warsaw, comrade Ho Guk Bon, on the initiative of North Korea, 24 June 1957: 8). It was hard to establish their Alma Mater or what happened to them later. They were probably sent to their motherland and there they received an intensive "ideological training". A similar situation occurred a year later in Hungary - during the Hungarian Revolution of 1956, a few North Korean students fled to the West. In response, the authorities in Pyongyang decided that all the DPRK citizens should be brought back to their homeland, where some of them would be accused of sympathizing with "revolutionists", spying for the U.S. and starting a revolution in North Korea (Armstrong 2013: 100; Scalapino, Lee 1972: 546-558). This was the reason why Kim II Sung carefully monitored "Gomułka's thaw" and ordered the North Korean Embassy to do the same as far as North Korean citizens in Poland were concerned.

In 1957, the Polish delegation, which was led by Józef Cyrankiewicz, revisited Pyongyang. The results of the talks didn't influence the relations between countries. The talks revolved mainly around the reunification of the Korean Peninsula, the activity of the Neutral Nations Supervisory Commission, and the situation in Hungary (Wspólne oświadczenie rządu...: poz. 76). On their way to Poland, the delegates met with Nikita Khrushchev in Moscow - one of the topics they discussed was the visit to North Korea. Cyrankiewicz pointed out that the North Korean authorities give too much consideration to massive state buildings rather than think about housing construction. The soviet leader remarked with a smirk that Kim "likes to exaggerate" (Korzon 1994: 113).

Kim II Sung finally dealt with the internal opposition in 1958 and, as the result, he gained dominance and stability on the North Korean political scene. At the turn of $1956 / 1957$, the DPRK decided to exchange their party cards. This procedure was intended to the political verification of the party members. It also gave the society the feeling of constant threat and made North Koreans afraid of expressing their opinions, especially those which were against the official political line. The condition of country isolation was also tightened. One of the truly symbolic events was that of 1958, when North Korea forced Kremlin to call all of its advisors away ${ }^{17}$ (Dziak 2000: 252-253).

In 1959, other Polish delegations of high-rank officials visited North Korea. They were rather courteous and didn't have any influence on Polish-North Korean relations. Choe En Hen, who had taken a position of the head of the Supreme People's Assembly after Kim Tu Bong ${ }_{1}^{18}$ met with the Polish authorities in Warsaw. During the talks, the Ministry of Foreign Affairs of Poland highlighted the importance of the Neutral Nations

\footnotetext{
${ }^{17}$ The Chinese army also left North Korea in 1958. See Shen, Xia 2012: 20-21.

${ }^{18}$ Due to political cleansing, Kim Tu Bong was removed and killed in unexplained circumstances in1958.
} 
Supervisory Commission as well as Polish participation in this Commission (Agenda for the talks with the delegation of the DPRK: 6). The same issue was discussed in 1956, during Kim's visit in Poland (Note of the Deputy Director of Department V of the Ministry of Foreign Affairs, Edward Słuczański...: 47). Poland wanted the Commission to continue, even though its capabilities were seriously limited after 1956.

As a response, the Polish delegation with the head of the State Council, Aleksander Zawadzki, went to Pyongyang. One of the members of the delegation was the future First Secretary of the Central Committee of the Polish United Workers' Party, Edward Gierek (Information note on the visit of the Polish delegation and comrade Aleksander Zawadzki to the DPRK...: 42). Talks and meetings were mainly focused on current issues and on the further political, economic, cultural, and scientific and technical cooperation between two countries. Poland perceived the visit as successful, however, Kim II Sung's absence during the public speeches was noticed (Information note on the visit...: 43). One of the topics covered was Khrushchev's recent visit to the US. Both countries approved of the peaceful coexistence policy propagated by the Soviet leader. North Korea also highlighted the inviolability of the Oder-Neisse border between Germany and Poland (Wspólny komunikat...: poz. 130).

The conflict between Beijing and Moscow was revealed internationally in April 1960 (Szalontai 2005: 161; Skobelski 2010: 113). Gomułka was aware that it wasn't only a matter of political differences between China and the Soviet Union - it was rather the conflict of interests and leadership. Due to internal ideological competition, another military conflict with the West, or China's confrontational policy, he feared that the Eastern Bloc would fall apart (Skobelski 2010: 113-114; 126-127).

At the beginning of the 1960s, the relations between North Korea and other satellite states, including Poland, were seriously limited. The deciding factors were the escalation of the conflict between China and the USSR and the harsh criticism of Chinese and North Korean leaders during the $22^{\text {nd }}$ Congress of the Communist Party of the Soviet Union in 1961. It had resulted in a closer relationship between Pyongyang and Beijing. Consequently, the DPRK reinforced its fight with "Khrushchev's revisionism" within the Workers' Party of Korea. Radio Pyongyang suspended a Korean radio program that had been broadcast by Radio Moscow, and also newspapers "Pravda" and "Kommunist" were withdrawn from sale (Szalontai 2004/2005: 97). At the end of 1961, the ambassadors of Bulgaria, Poland, Hungary and East Germany met in order to discuss the Soviet-North Korean relations of that time. The diplomats agreed that the supporters of China had a major impact on the leaders of the Workers' Party of Korea and that Kim II Sung had taken a clear stand in the Sino-Soviet conflict, supporting the authorities in Beijing (Shafer 2003/2004: 29).

The Polish-North Korean relations after 1961 may be described as correct, but not so intensive when compared to the former decade. At the end of June 1961, even before the changes that would be made during the $22^{\text {nd }}$ Congress of the Communist 
Party of the Soviet Union, Poland and North Korea signed the agreement on lending the DPRK money for the supply of complete industrial plants and the agreement on the mutual supply of goods and payments for the years of 1962-1965 (Szczepanik, Herman- $Ł u k a s i k$, Janicka 2010: 167-168). The attitude of the authorities in Pyongyang towards Poland was reflected by the number of visits they made to Warsaw. In 1961, which was the breakthrough year for North Korea, the DPRK leaders visited Poland only four times - that ranked Poland last but one when it comes to the number official visits (the last was Yugoslavia). For comparison, the most visited countries were Czechoslovakia and East Germany - they hosted the official delegation of North Korea 15 and 16 times respectively (Scalapino, Lee 1972b: 738).

\section{Conclusion}

The warming of Polish-North Korean relations could be observed after Nikita Khrushchev's death in 1964, when the authorities in Pyongyang turned itself once again to Kremlin. During the highest political tensions their relations were limited to the minimum. The visits of the high-rank officials delegations were cancelled, the countries didn't sign any agreements concerning their further cooperation. In November 1965, the rapprochement between two countries could be observed - they signed two agreements, one on the mutual supply of goods and payments for the years of 19651967, and the other on forming the Polish-Korean Association of Ship Agents (later transformed into still existing, and a bit controversial, Chopol company). In the following years, the political and governmental contacts were also intensified. Poland as well as North Korea perceived their relations in the 1960 s as good, , however, they didn't treat each other as the objects of great interest.

\section{Bibliography}

\section{Polish Diplomacy Archive}

Independent Eastern Department

Juliusz Burgin's report of the first journey to Korea presented to E. Słuczański, the head of the Independent Eastern Department of the Ministry of Foreign Affairs, 2 January 1951, zesp. 11, w. 22, t. 414.

Written account of the conversation with the Second Secretary of the North Korean Embassy, Li Sen Yen, that took place in the Independent Eastern Department of the Ministry of Foreign Affairs, 10 October 1951, zesp. 11, w. 22, t. 419.

Resolution no. 140/53 of the Presidium of the Government dated 14 February 1953 on the cancellation of the DPRK's liability under the agreement on supplying of goods on credit terms from Poland to North Korea signed on 2 June 1952, zesp. 11, w. 24, t. 447.

Letter to Minister Naszkowski, 14 February 1953, zesp. 11, w. 24, t. 448. 


\section{Diplomatic Protocols 1948-1963}

Note of the Deputy Director of Department V of the Ministry of Foreign Affairs, Edward Słuczański, to the Deputy Naszkowki on the visit of the North Korean delegation to Poland, 27 July 1956, zesp. 16 w. 28 t. 464.

Written account of the conversation between the First Secretary of the Embassy of the Polish People's Republic in Pyongyang, H. Brzeziński, and the Counselor and the First Secretary of the Embassy of the Soviet Union, 12 May 1056, zesp. 16, w. 28, t. 464.

Note on the economic relations between the Polish People's Republic and the DPRK, zesp. 16, w. 28, t. 464. Biography of Cze-Ir, proposed for the position of the Ambassador of the DPRK in Warsaw, zesp. 16, w. 28, t. 476 .

\section{Department V}

Note on media reports in North Korea on the 1956 events in Poland, 10 November 1956, zesp. 12, w. 18, t. 420.

Written account of the talks between the delegations of the Polish People's Republic and the DPRK in Pyongyang, 15 April 1957, zesp. 12, w. 18, t. 423.

Written account of the conversation with Li Son-Lon, the Counselor of the Embassy of the DPRK in Warsaw, that took place in Department V on the initiative of North Korea, 7 October 1957, zesp. 12, w. 18, t. 424.

Written account of the conversation with the Charge d'Affaires of the DPRK, comrade Li Son-Lon, on the initiative of the Embassy of the DPRK, 28 May 1957, zesp. 12, w. 18, t. 424.

Written account of the conversation with the Ambassador of the DPRK in Warsaw, comrade Ho Guk Bon, on the initiative of North Korea, 24 June 1957, zesp. 12, w. 18, t. 424.

Information note on the visit of the Polish delegation and comrade Aleksander Zawadzki to the DPRK, zesp. 12, w. 51, t. 994.

Agenda for the talks with the delegation of the DPRK, 1959, zesp. 12, w. 51, t. 994.

Case of the return of North Korean orphans to their motherland, zesp. 12, w. 41, t. 1092.

\section{Polish Central Archive of Modern Records in Warsaw}

\section{Ministry of Education}

Report on North Korean missions in Poland, at the date of 10 October 1953, 283/3807.

\section{Ministry of Higher Education}

Table presenting the number of foreign students in Poland for the year of 1955, 317/474.

\section{Council of Ministers Office}

Resolution no. 685/53 of the Presidium of the Government dated 12 September 1953 on the establishment and maintenance of the Polish delegation in the Neutral Nations Repatriation Commission in Korea, 159/80.

Resolution no. 686/53 of the Presidium of the Government dated 12 September 1953 on the establishment and maintenance of the Polish delegation in the Neutral Nations Supervisory Commission in Korea, 159/82.

Resolution no. 732/53 of the Presidium of the Government dated 24 September 1953 on the assistance for the Democratic People's Republic of Korea, 159/84.

Resolution no. 910/53 of the Presidium of the Government dated 28 November 1953 on settling up the special Military Unit No. 2000, 159/104. 


\section{Cultural Cooperation Commettiee in Warsaw 1950-1956}

Political report of the Embassy of Polish People's Republic in the DPRK for the period from 15 April to 15 May $1956,175 / 119$.

Armstrong C.K., 2005, "Fraternal Socialism": The International Reconstruction of North Korea, 19531962, “Cold War History”, No. 2.

Armstrong C.K., 2013, Tyranny Of The Weak: North Korea And The World, 1950-1992, New YorkLondon: Ithaca.

Bayer J., Dziak W.J., 2006, Korea \& Chiny, t. 1: Strategia i polityka, Warszawa: Instytut Studiów Politycznych PAN.

Benken P., 2014, Problematyka stosunków między Misją Polską do Komisji Nadzorczej Państw Neutralnych a Sztabem Wojskowej Komisji Rozejmowej strony Koreańskiej Armii Ludowej/Chińskich Ochotników Ludowych w Kaesongu oraz wytyczne w tej sprawie, "Pamięć i Sprawiedliwość", nr 23.

Birchmeier Ch., Burdelski M., 2003, Jendraszczak E., 50-lecie Komisji Nadzorczej Państw Neutralnych, Toruń: Wydawnictwo Adam Marszałek.

Brandys M., 1953, Dom odzyskanego dzieciństwa, Warszawa: Nasza Księgarnia

Brandys M., 1954, Koreańczycy z Gołotczyzny, Warszawa: Czytelnik.

Broniarek Z., 1952, Amerykańska zaraza nad Koreq̨, Warszawa: Książka i Wiedza.

Brzechwa J., 1952, Koreańska piosenka [in:] Cięte bańki, Warszawa: Czytelnik.

Burdelski M., 2004, Czynniki warunkujące proces podziału i zjednoczenia Korei, Toruń: Adam Marszałek.

Burdelski M., 2008, Misja polska w Komisji Nadzorczej Państw Neutralnych w Korei. Genezastruktura-funkcje, "Studia Gdańskie. Wizje i rzeczywistość", t. V.

Codogni P., 2006, Rok 1956, Warszawa: Prószyński i S-ka.

Czyżewski M., 2005, Propaganda polityczna władzy ludowej w Polsce 1944-1956, Toruń: Wydawnictwo Naukowe Grado.

Dziak W.J. 2009, Korea Północna. U źródeł rodzinnej sukcesji władzy, Warszawa: Collegium Civitas, Instytut Studiów Politycznych PAN.

Dziak W.J., 2000, Kim Ir Sen. Dzieło i polityczne wizje, Warszawa: Instytut Studiów Politycznych PAN.

Gaj K., Zuziak J., 2011, Wojsko Polskie w międzynarodowych misjach pokojowych (1953-2011), „Przegląd Historyczno-Wojskowy", nr 5.

Hastings M., 2010, Wojna koreańska, Wrocław: Wydawnictwo Dolnośląskie.

Jarosz D., 1997, Polacy wobec groźby wybuchu wojny w świetle przekazów potocznych z lat 1946-1956, "Dzieje Najnowsze", nr 2.

Kim J.S., 2014, Polish Aid for North Korea during the Korean War, in „East European \& Balkan Studies", Vol. 38, No. 6.

Korotyński H., 1952a, Dwie wojny w Korei, Warszawa: Wydawnictwo Ministerstwa Obrony Narodowej. Korotyński H., 1952b, 10 tygodni w Korei, Warszawa: Książka i Wiedza.

Korzon A., 1994, Rozmowa Cyrankiewicza z Chruszczowem w kwietniu 1957 r., "Studia z dziejów Rosji i Europy Środkowo-Wschodniej", t. 29.

Labuda G., Miechowicz W., 2002, Historia dyplomacji polskiej X-XX w., Warszawa: Wydawnictwo Sejmowe. 
Lankov A., 2007, Crisis in North Korea. The Failure of De-Stalinization, 1956, Honolulu: University of Hawaii Press.

Leszczyński A., 1995, Wojna koreańska w propagandzie polskiej od czerwca do grudnia 1950 r., „Przegląd Historyczny", vol. 86, no. 1.

Levi N., 2009, Zarys stosunków między Polską Rzeczpospolitq Ludowq a Koreańską Republikq̨ Ludowo-Demokratyczną [in:] Świat i Polska wobec wyzwań globalnych, red. R. Żelichowski, Warszawa: Collegium Civitas, Instytut Studiów Politycznych PAN.

Levi N., Naumczyk A., 2012, Zarys stosunków między Polskq a Koreq Północnq [in:] Korea Północna. Poszukując Prawdy. Kwiaty Orientu, Skarżysko Kamienna: Kwiaty Orientu.

Lowe P., 1995, Wojna koreańska, Warszawa: Bellona.

Łagojda K., 2017, Działania propagandowe wokół Apelu sztokholmskiego w 1950 roku na przykładzie województwa wrocławskiego [in:] Jak patrzeć na Polskę, Niemcy i świat. Księga Jubileuszowa profesora Eugeniusza Cezarego Króla, red. J. Szymoniczek, Warszawa:

Machcewicz P., 1993, Polski rok 1956, Warszawa: Mówią Wieki.

Makowski E., 2001, Poznański Czerwiec 1956. Pierwszy bunt społeczeństwa w PRL, Poznań: Wydawnictwo Poznańskie.

Matusik M., 2015, „Jesteśmy z Wami, ludzie walczącej Korei”. Obraz Korei Północnej w Polskiej Kronice Filmowej 1947-1989, „Ogrody Nauki i Sztuki", nr 5.

Myers B.R., 2015, North Korea's Juche Myth, Busan: Sthele Press.

Neścioruk P., 2014, Propagandowy obraz genezy wojny koreańskiej w świetle „Trybuny Ludu”, „Teka Komisji Historycznej O.L. PAN", t. XI.

Pracki L., 1953, Korespondent wojenny z Korei donosi, Warszawa: Wydawnictwo Ministerstwa Obrony Narodowej.

Scalapino R.A, Lee Ch.S., 1972a, Communism in Korea, p. 1: The Movement, Berkley-Los AngelesLondon: University of California Press.

Scalapino R.A, Lee Ch.S., 1972b, Communism in Korea, p. 2: The Society, Berkley-Los AngelesLondon: University of California Press.

Shäfer B., 2003/2004, Seathering the Sino-Soviet Conflict: The GDR and the North Korea, 1949-1989, "Cold War International History Project Bulletin", No. 14/15.

Shen Z, Xia Y., 2012, China and the post-war reconstruction of North Korea, 1953-1961, Washington: Woodrow Wilson International Center for Scholars.

Skobelski R., 2010, Polityka PRL wobec państw socjalistycznych w latach 1956-1970. Współpraca napięcia - konflikty, Poznań: Wydawnictwo Poznańskie.

Sołtysik Ł., 2009, Dzieci i młodzież północnokoreańska w Polsce w latach 1953-1954 w świetle wybranych dokumentów, „Rocznik Jeleniogórski”, nr 41.

Sołtysik Ł., 2010, Dzieci i młodzież północnokoreańska na Dolnym Śląsku i Mazowszu w latach 19511959, „Śląski Kwartalnik Historyczny Sobótka”, nr 1.

Strand G., 2014, Korea. Polityka Południa wobec Północy w latach 1948-2008. Zmiana i kontynuacja, Poznań: Instytut Zachodni.

Szalontai B., 2005, Kim II Sung in the Khrushchev Era. Soviet-DPRK Relations and the Roots of North Korean Despotism, 1953-1964, Washington: Stanford University Press.

Szalontai B, 2003/2004, "You Have No Political Line of Your Own”. Kim II Sung and the Soviets, 19531954, "Cold War International History Project Bulletin", No. 14/15. 
Szczepanik K., Herman-Łukasik A., Janicka B., 2010, Stosunki dyplomatyczne Polski. Informator, t. 3: Azja, Zakaukazie, Australia i Oceania 1918-2009, Warszawa: Wydawnictwo Askon.

Szyc S., 2014a, Północnokoreańskie dzieci oraz młodzież w Państwowym Ośrodku Wychowawczym w Płakowicach na Dolnym Ślasku w latach 1953-1959, Rodzina: powołanie, zadania, zagrożenia, red. J. Zimny, Stalowa Wola: KUL.

Szyc S., 2014b, Sprawa powrotu do ojczyzny dzieci oraz młodzieży północnokoreańskiej przebywającej w Polsce w l. 1951-1959 w świetle wybranych dokumentów, „Koło Historii", nr 15.

Szyc S., 2015a, Polscy ambasadorowie w Koreańskiej Republice Ludowo-Demokratycznej w latach 1950-1963 [in:] Elity komunistyczne w Polsce, red. M. Szumiło, M. Żukowski, Warszawa-Lublin: Instytut Pamięci Narodowej, Wydawnictwo UMCS.

Szyc S., 2015b, Program pomocy Polskiej Rzeczypospolitej Ludowej dla Koreańskiej Republiki Ludowo-Demokratycznej w świetle wybranych dokumentów , ,Komunizm: system-ludzie-dokumentacja”, nr 4.

Szyc S., 2016, Misja przyjaźni. Oficjalna wizyta Kim Ir Sena w Polskiej Rzeczypospolitej Ludowej w lipcu 1956 r. [in:] IX Letnia Szkoła Historii Najnowszej IPN, red. Ł. Kamiński, J. Szumski, Warszawa: Instytut Pamięci Narodowej.

Szymborska W., 1952, Z Korei [in:] eadem, Dlatego żyjemy, Kraków: Czytelnik.

Tebinka J., 2010, Uzależnienie czy suwerenność? Odwilż październikowa w dyplomacji Polskiej Rzeczypospolitej Ludowej 1956-1961, Warszawa: Neriton-Instytut Historii PAN.

Wspólne oświadczenie rzq̨du PRL i rzq̨du Koreańskiej Republiki Ludowo-Demokratycznej w Pjongjangu z dnia 17 kwietnia 1957 r., 1957, "Zbiór Dokumentów 1957" poz. 76, R. 13 nr 4, Warszawa, on-line: http://digit.pism.pl/dlibra/docmetadata?id=386\&fro.

Wspólny komunikat polsko-koreański w Pjongjangu z dnia 19 października 1959 r., 1959, "Zbiór Dokumentów 1959" poz. 130, T. 15, nr 10-12, Warszawa, on-line: http://digit.pism.pl/dlibra/ docmetadata?id=209\&from=publication. 